\title{
Ecological state of the urban environment as an object of forensic analysis within the period of introducing the judicial reform of Russia
}

\author{
Elena Voskresenskaya $^{1 *}$, Dmitry Mokhorov ${ }^{1}$ and Alexander Tebryaev $^{1}$ \\ ${ }^{1}$ Peter the Great St.Petersburg Polytechnic University, 195251, St. Petersburg, Polytechnicheskaya \\ str., 29, Russia
}

\begin{abstract}
For today, environmental protection is one of the most serious issues for the government. The urban environment is exposed to numerous negative natural and anthropogenic processes. The scientific article considers the main problems of forensic analysis of the ecological state of the urban environment. Reduction in the scope of environmental expertise caused by urban development reformation became the negative matter. The authors believe that the forensic analysis is an important legal instrument for ensuring rational environmental resources management and environmental protection from harmful impacts on urban areas. Along with rationing, licensing, certification, audit, the forensic analysis performs the function of environmental control, acting as a guarantor of compliance with legal requirements. In order to integrate new kinds (types) of forensic analysis into a unified list of kinds (types) of analysis and to regulate the existing lists, the adoption of the National Standard on Forensic Ecological Expert Analysis is demanded; however, the adoption of a unified National Standard of the Russian Federation on forensic analysis is also required.
\end{abstract}

\section{Introduction}

Over the last years, the study of ecological state of urban environment objects became very relevant. In accordance with the Federal Laws «On Environmental Protection», «On Environmental Expertise», permanent monitoring of the quality of the environment in cities and other settlements is carried out. Decisions on the plans for social and economic development, the implementation of various projects, construction and operation of industrial facilities, urban and municipal services are made based on the positive conclusion of the state environmental review. The results of environmental monitoring and sanitaryepidemiological survey enable determining the eligibility of economic and other activities of urban environment.

The urban environment is exposed to numerous negative natural and anthropogenic processes. The scientific article considers the main problems of forensic analysis of the ecological state of the urban environment. Reduction in the scope of environmental expertise caused by urban development reformation became the negative matter. During

\footnotetext{
${ }^{*}$ Corresponding author: elenvoskr@mail.ru
} 
different years, the legal institute of ecological analysis has been studied by such leading scientists belonging to this field of legal regulation as E. A. Maltseva [1], M. V. Matveeva [2], S.I. Sai [3], D. V. Khustov [4], M.V. Hotuleva [5] and others. The authors [6, 7, 8] of the article focused on certain problems of legal regulation of forensic analysis of the urban environment as well. It also should be noted that for the past five years there has been a significant decrease in the scientific interest in this issue, there are fewer and fewer publications on this issue, and not much attention is paid to it in the educational literature.

\section{Materials and Methods}

The urban environment is exposed to numerous negative natural and anthropogenic processes. It is worth to point out from them the pollution of urban environment with environmentally hazardous substances, increase in the level of harmful physical impact, including noise, vibration, electromagnetic, reducing greenery, increase in the area of anthropogenically disturbed lands, and water balance disrupting (flooding or drying). Objects of the urban environment are exposed to the simultaneous impact of several negative processes, which often leads to increase of consequences resulting from their interaction.

The protection and improvement of the urban environment, as well as solving the problems of ensuring environmental, technological and anti-terrorist security are the subjects of great attention. However, the implementation of a set of measures (including the use of highly efficient gas and dust collecting devices, the use of non-waste technologies, switching to clean fuels, site landscaping) does not always lead to the intended result. Despite the legislative support for the incorporation of environmental requirements for the placement, design, construction, reconstruction of urban environment facilities, in most of cities there is a negative anthropogenic impact of transport, industrial and housing utilities on urban facilities, which exceeds the established norms. Solving problems of environmental pollution with waste products and household waste is relevant today. The solution of the listed problems indicates the need to form an independent direction of forensic environmental research, particularly forensic environmental analysis of urban environment.

\section{Results}

When carrying out a forensic analysis for the expert's license, diagnostic and identification questions are raised. Thus, the diagnosis in forensic analysis lies in determining the mechanism of the event, time, kind and order of actions, phenomena, causal relationships between them, nature, qualitative and quantitative characteristics of objects, their properties and attributes that can not be directly perceived, etc. Diagnostic issues include the determination of the scale and circumstances of the negative anthropogenic impact on soilgeological objects caused by oil spills and the setting of mechanism of a negative radioactivity impact.

Identification in forensic analysis is the process of establishing the identity of an individually defined object, which is one of the means of establishing the truth in legal proceedings. The following examples of identification issues of forensic environmental examination and be given: the detection of a source of negative anthropogenic impact on soil-geological objects, the determination of a specific potentially hazardous facility, which became the site of the emergence of negative radioactive effects. In criminal, civil and arbitration courts, the expert's identification report is one of the most important evidentiary arguments. 


\section{Discussion}

The objects of forensic research are a local land parcel with signs of negative anthropogenic impact; samples of atmospheric air, water, soil, selected within the anthropogenically disturbed environment; specimens of flora and fauna affected by negative anthropogenic influences; mechanisms, equipment or its parts from the place where the event occurred; information from technical documentation and acts of the ecological state inspection of facilities; the results of a survey of environmental objects by sanitary-epidemiological, environmental and other specially authorized bodies.

The subject of forensic environmental examination of the urban environment is the actual circumstances evidencing negative anthropogenic impact on specific objects of the urban environment, including buildings, structures and areas functionally connected with them, which are established on the basis of the use of special knowledge in the field of ecology and related sciences in the process criminal, civil and administrative proceedings. Table 1 shows the statistics of the number of production and consumption wastes in Russia for 2012-2015 [9].

Table 1. Formation of production and consumption wastes by types of economic activity, million tons

\begin{tabular}{lrrrr}
\hline Types of economic activity & 2012 & 2013 & 2014 & 2015 \\
\hline Totaly, including: & $\mathbf{5 0 0 7 . 9}$ & $\mathbf{5 1 5 2 . 8}$ & $\mathbf{5 1 6 8 . 3}$ & $\mathbf{5 0 6 0 . 2}$ \\
agriculture, hunting and forestry & 26.1 & 40.3 & 43.1 & 45.8 \\
mining & 4629.3 & 4701.2 & 4807.3 & 4653.0 \\
manufacturing industries & 291.0 & 253.7 & 243.1 & 282.9 \\
$\begin{array}{l}\text { production and distribution of } \\
\text { electricity, gas and water }\end{array}$ & & & & \\
transport and communications & 28.4 & 24.1 & 28.3 & 26.4 \\
$\begin{array}{l}\text { provision of other communal, } \\
\text { social and personal services }\end{array}$ & 3.1 & 4.5 & 3.9 & 2.9 \\
\hline
\end{tabular}

Table 2 provides statistics on the use and disposal of waste in Russia for 2012-2015 [9].

Table 2. Use and neutralization of production and consumption wastes by types of economic activity, million tons.

Table 3 provides statistics on the costs of protecting the urban environment in Russia in 2012-2015 by sectors of the economy [9].

Table 3. Costs for environmental protection by sector of the economy, million rubles.

\begin{tabular}{lrrrr}
\hline Types of economic activity & 2012 & 2013 & 2014 & 2015 \\
\hline Totaly, including: & $\mathbf{4 4 5 8 1 7}$ & $\mathbf{4 7 9 3 8 4}$ & $\mathbf{5 3 5 6 3}$ & $\mathbf{5 6 2 4 4 9}$ \\
commercial sector & 352638 & 373810 & 422331 & 439748 \\
sector of $\quad$ specialized & & & & \\
environmental service providers & 50018 & 58526 & 67166 & 73041 \\
government sector & 43160 & 47047 & 46366 & 49659 \\
\hline
\end{tabular}

Table 4 shows the statistics on the costs of protecting the urban environment in Russia in 2012-2015 by the directions of activity [9].

Table 4. Costs for environmental protection by the directions of environmental protection activity, mln. rub.

\begin{tabular}{lrrrr}
\hline Types of economic activity & 2012 & 2013 & 2014 & 2015 \\
\hline Total, including: & $\mathbf{4 4 5 8 1 7}$ & $\mathbf{4 7 9 3 8 4}$ & $\mathbf{5 3 5 8 6 3}$ & $\mathbf{5 6 2 4 4 9}$
\end{tabular}




\begin{tabular}{|c|c|c|c|c|}
\hline atmospheric air protection & 89236 & 93251 & 112412 & 103950 \\
\hline collection and treatment of waste & & & & \\
\hline water & 186445 & 204351 & 223439 & 234112 \\
\hline waste treatment & 41022 & 51612 & 60885 & 68483 \\
\hline $\begin{array}{l}\text { protection and rehabilitation of } \\
\text { lands }\end{array}$ & 36498 & 33486 & 36105 & 37952 \\
\hline $\begin{array}{l}\text { conservation and protection of } \\
\text { natural areas }\end{array}$ & 28091 & 28082 & 34489 & 45893 \\
\hline other & 64525 & 68602 & 68533 & 72059 \\
\hline
\end{tabular}

All major cities of the country have similar problems: overpopulation, polluted air, noise, untreated sewage and water, which is unsuitable for consumption. Environmental problems of St. Petersburg are caused by the fact that industry is mainly concentrated within the city. The city industry involves the production of coke and petroleum products, ferrous and nonferrous metallurgy, heavy engineering, food and chemical industries. The main sources of pollution are such enterprises of these industries as: «Sredne-Nevsky Shipbuilding Plant», «Admiralty Shipyards», «Electrosila», «Kirovsky Plant», «Svetlana», «Baltiysky Plant», «Severnaya Shipyard», «Krasny Vyborzhets», «Baltika», «Heineken Brewery».

More than 500 thousand tons of pollutants are released into the atmosphere each year. St. Petersburg has become one of the most polluted cities in Russia, after Moscow and Norilsk, in terms of this factor. The main source of pollution is motor transport: its share in the pollution of environment is almost $86 \%$ of the total. The maximum allowable concentrations of substances such as nitric oxide, carbon monoxide and benzene, nitrogen dioxide, are several times exceeded. The city stretches for a distance of more than $90 \mathrm{~km}$, therefore the population has to use a significant amount of transport, which is the main source of noise.

The Neva River is the main waterway of the city. The length of all streams is about 282 $\mathrm{km}$, the area of the river amounts $7 \%$ of the total area of St. Petersburg. Water of the Neva, as well as of the Gulf of Finland, is considered environmentally unsatisfactory because it is polluted by industrial and sewage water, waste from enterprises and household waste, oil spills. Up to 100 thousand tons of such pollutants and more than 40 oil spills are discharged in the river per year. All beaches of the city are considered as unsuitable for swimming. Wastes from industrial production and solid households, which form more than 1700 thousand tons per year, are exported to three municipal landfills and the «Krasny Bor» landfill, designed for the disposal of toxic waste. However, there is a problem of waste processing, only $15 \%$ of total volume of which is exposed. Two garbage-processing plants, two sorting lines and the plant «Quantum», which is not brought into operation, are engaged in this.

\section{Conclusions}

The forensic ecological analysis department was created in the Russian Federal Center of Forensic Analysis under the Ministry of Justice of Russia. In accordance with the decree No. 237 of the Ministry of Justice of December 27, 2012, environmental expertise was determined as an independent kind of forensic examination, which is currently divided into the following types: the study of the ecological state of objects of soil-geological origin; the study of the ecological state of natural and artificial biotic communities and the study of the radiation situation. The specialists with higher ecological, biological, geographical, soilagrochemical or technical education, who have received special training, received a entitlement certificate giving the right to independently produce expertise on expert environmental specialties, the ones, who specialize in the study of its various components 
for the administration of justice, can be the state forensic experts in the field of forensic environmental analysis.

Employees of specially authorized bodies in the field of nature management and environmental protection are often involved in the performance of this analysis. The main differences between forensic-environmental analysis and state environmental expertise are in objects, subjects and aims. The performance of state ecological expertise in accordance with Art. 33 of the Federal Law «On Environmental Protection» and art. 1 of the Federal Law «On Environmental Assessment» determines the compliance of the planned economic and other activities with the requirements of environmental legislation. The procedure for carrying out the state environmental review is regulated by the relevant provision. The production of forensic environmental examination is carried out in accordance with the procedural legislation and the Federal Law «On state forensic expert activity», is associated with legal proceedings and requires the use of special knowledge in the field of ecology and related natural sciences in order to define the actual circumstances of the event under consideration.

In order to integrate new kinds (types) of forensic analysis into a uniform list of kinds (types) of analysis and to regulate the existing lists, the authors propose to develop and adopt The National Standard on forensic analysis of the Russian Federation, which is supposed to include the provisions on a uniform list of types of forensic analysis and a uniform list of expert specialties granting the right to independently produce forensic analysis on the basis of a classification developed in forensic expertology. The requirements of the Standard are proposed to be spread among all state forensic institutions of federal executive bodies, regardless of their departmental subordination, and among nongovernmental expert institutions, as well as among private experts. To date, only the Russian National Standard on Forensic Ecological Expertise has been adopted.

\section{References}

1. A. Mottaeva, J. Ćetković, Advances in Intelligent Systems and Computing, vol 692, pp. 1151-1159 (2018) doi.org/10.1007/978-3-319-70987-1_123

2. L.N.Nikolova, D. G. Rodionov, M.A.Bahauovna, International Journal of Economics and Financial 6(2), 246-252 (2016)

3. S.I. Sai Gosudarstvennaya ekologicheskaya ekspertiza v Rossii: stanovlenie, razrushenie, vozrozhdenie 6 16-20 pp (2014)

4. A. Mottaeva, IOP Conf. Series: Earth and Environmental Science 90, 012124 (2017) doi :10.1088/1755-1315/90/1/012124

5. A. Mottaeva MATEC Web of Conferences, 106, 08071 (2017) https://doi.org/10.1051/matecconf/201710608071

6. E. Voskresenskaya, V. Snetkov Alexander Tebryaev and Zokhidjon Askarov MATEC Web of Conferences 10608055 (2017)

7. E. Voskresenskaya, V. Snetkov and A. Tebryaev E3S Web of Conferences 33, 03051 (2018) doi.org/10.1051/e3sconf/20183303051

8. E. Voskresenskaya and L. Vorona-Slivinskaya V E3S Web of Conferences 33, 03052 (2018) https://doi.org/10.1051/e3sconf/20183303052

9. Regiony Rossii/ Sotsial'no-ekonomicheskie pokazatel. R32 (2017) 